\title{
FUNCTIONS OF TOCOPHEROLS IN THE CELLS OF PLANTS AND OTHER PHOTOSYNTHETIC ORGANISMS
}

\author{
V. M. MOKROSNOP \\ M. G. Kholodny Institute of Botany, National Academy of Sciences of Ukraine, Kyiv; \\ e-mail:VictoryM6@yandex.ua
}

Tocopherol synthesis has only been observed in photosynthetic organisms (plants, algae and some cyanobacteria). Tocopherol is synthesized in the inner membrane of chloroplasts and distributed between chloroplast membranes, thylakoids and plastoglobules. Physiological significance of tocopherols for human and animal is well-studied, but relatively little is known about their function in plant organisms. Among the best characterized functions of tocopherols in cells is their ability to scavenge and quench reactive oxygen species and fat-soluble by-products of oxidative stress. There are the data on the participation of different mechanisms of $\alpha$-tocopherol action in protecting photosystem II (PS II) from photoinhibition both by deactivation of singlet oxygen produced by PS II and by reduction of proton permeability of thylakoid membranes, leading to acidification of lumen under high light conditions and activation of violaxanthin de-epoxidase. Additional biological activity of tocopherols, independent of its antioxidant functions have been demonstrated. Basic mechanisms for these effects are connected with the modulation of signal transduction pathways by specific tocopherols and, in some instances, by transcriptional activation of gene expression.

Ke y word s: antioxidant, plastids, thylakoids, chloroplast, tocopherols, tocotrienols, oxidative stress, lipid peroxidation, photosynthesis, vitamin E.

\section{Study of tocopherols functions}

The term «tocopherols» unites all mono-, diand trimethylated tocols and tocotrienols. Four isoforms $(\alpha, \beta, \gamma, \delta)$ of tocopherols and tocotrienols, which differ in the number and positions of methyl groups in the chromanol ring, are found in nature (Fig. 1). Eight forms of tocopherols, isolated from plant sources, consist of a 6-chromanol ring and a hydrophobic phytyl side chain. Tocotrienols have a similar structure, differ from tocopherols only by the fact that their side phytyl chains have three double bonds in positions $3^{\prime}, 7^{\prime}$ and $11^{\prime}$. The biological activity of tocopherols depends on their structure, distribution of side radicals and stereoisomerism of the carbon chain. $\alpha$ form is the most biologically active one among four tocopherol izoforms. Its activity taken as $100 \%$, the activities of $\beta, \gamma$ and $\delta$ - forms are 30,15 and 5\%, respectively. Thanks to the presence of methyl group in the aromatic ring of tocopherols, those molecules are thermostable, resistant to the action of acids and alkalies [1]. Tocopherols are synthesized exceptionally by photosynthetic organisms (plants, algae and the majority of cyanobacteria) [2, 3]. Synthesis occurs in plastids, where tocotrienols and tocopherols are formed from homogentisic acid and phytyl diphosphate or geranylgeranyl diphosphate, correspondingly. Enzymes involved in the synthesis of tocopherols are associated with plastid membranes, and vitamin $\mathrm{E}$ is distributed between plastid membranes and plastoglobules [4].

Functions of vitamin $\mathrm{E}$ in animals and human have been studied extensively, however, despite the fact that photosynthesizing organisms are the only source of vitamin E, few researches are devoted to determination of tocopherols and tocotrienols functions in plants and algae.

It was believed up to the 1990's that the function of $\alpha$-tocopherol in plants is associated only with antioxidant activity and maintenance of membrane integrity. Later it was found that, besides photo- and antioxidant protective functions, $\alpha$-tocopherol is able to play a role in transmission of cellular signals in plants, just the same as in animal cells. Experiments performed on mutant plants, unable to tocopherol synthesis, have proved this assumption and, thus, varied functions of these compounds [4].

\section{Localization of tocopherols and tocotrienols}

Numerous studies have showed that tocopherols and tocotrienols in plants are located in plastids: 


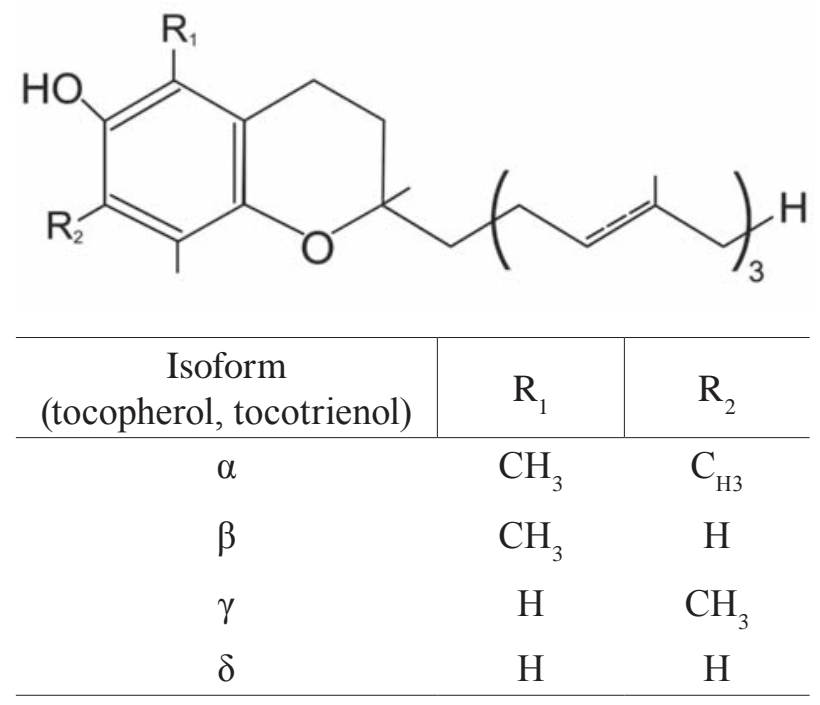

Fig. 1. Chemical formula of tocochromanols

in amyloplasts of seeds and bulbs, chloroplasts of photosynthesizing tissues, in leucoplasts of petalsand in chromoplasts of fruits $[5,6]$. $\alpha$-Tocopherol has been found in barley leaves not only in the chloroplasts, where its content varies from 48 to $57 \%$, but also in the vacuole, which contains up to $18 \%$ of its total quantity. $\alpha$-Tocopherol was also found in the microsomal membranes of soy roots $(12 \mu \mathrm{g}$ of $\alpha$-tocopherol/g of proteins) [7].

$\alpha$-Tocopherol is synthesized on the inner membrane of plastids and distributed between chloroplast envelope and thylakoid membranes [7, 8]. A part of $\alpha$-tocopherol is stored in plastoglobules, located in the stroma of chloroplasts [5, 9]. One third of the total content of $\alpha$-tocopherol in chloroplasts of spinach is localized in the membrane of envelope and the other two thirds in thylakoid membranes. $\alpha$-, $\beta$ - and $\gamma$-tocopherols are present in spinach thylakoids in the molar ratio 1: 0.06: 0.02 , respectively. Tocopherols in membranes are not connected with protein domains and are present only in the lipid matrix of thylakoid and chloroplast membranes [7, 8].

Excessive amounts of tocopherols, which cannot be stored in the thylakoids, come to plastoglobules - a regular ball-like osmiophil plastid structures, which are also reservoirs for excess lipids. Plastoglobules in young leaves are few and have relatively small size (diameter range: 0.07-0.2 $\mu \mathrm{m}$ ). With increasing age of leaves and chloroplasts, the number and size of plastoglobules increase, especially in the leaves, which are regularly getting enough light and have high photosynthetic activity [5, 9].

\section{Antioxidant properties of tocopherols}

In plant organisms constantly generated reactive oxygen species (ROS) (singlet oxygen $\left({ }^{1} \mathrm{O}_{2}\right)$, superoxide anion $\left(\mathrm{O}_{2}\right)$, hydrogen peroxide $\left(\mathrm{H}_{2} \mathrm{O}_{2}\right)$, hydroxyl radical ( $\mathrm{HO}^{*}$ ), which have high activity and toxicity, and can lead to oxidative damage of cells. The main sources of ROS in the light are chloroplasts and peroxisomes, and in the dark mitochondria [10]. Unfavorable conditions of plant growth, for example, deviations from optimal temperature, availability of water, heavy metals effect, air pollution, shortage of nitrogen or salt stress can stimulate the production of ROS [11]. In response to the potential threat an effective antioxidant defense system was developed, that includes enzymatic and non-enzymatic components. The latter includes tocopherols - the main fat-soluble antioxidants in plant cells. Antioxidant activity of tocopherols is provided by their ability to deactivate free radicals and act as hydrogen donors, and is dependent on the structural features of molecules such as the level of methylation of aromatic ring $(\alpha>\beta=\gamma>\delta)$, size of heterocyclic ring, stereochemistry at position 2 and length of phytyl chain. The main functions of tocopherols are determined by the localization of side groups and amphipathic properties. Hydrophobic phytyl chain of the fat-soluble tocopherol molecules is associated with membrane lipids and the chromanol part of molecule with polar groups, which are located on the surface of membrane $[4,12]$. Tocopherols decrease the level of ROS, mainly ${ }^{1} \mathrm{O}_{2}$ and $\mathrm{HO}^{\cdot}$ in the thylakoid membranes and limit the degree of lipid peroxidation by reducing the lipid peroxyl radicals [12-14].

Peroxide oxidation of lipids (POL) is considered as the most harmful process that occurs in all living organisms. Its level indicates the degree of damage components of plant cells under various stress factors. The result of the lipid peroxidation is the increase of membrane fluidity, which facilitates the movement of phospholipids between the layers of membrane, increases its permeability to substances that normally pass through specific channels, increase the membrane protein damages and inactivation of receptors, enzymes, ion channels [15]. POL takes place in several phases, the first of which is induced by ROS, mainly $\mathrm{HO}^{\circ}$, and consists in conversion of (poly)unsaturated fatty acid to alkyl radical. The latter has high activity and interacts easily with oxygen, and transforms into peroxyl radical. POL chain is continued under conditions of inter- 
action of the new (poly)unsaturated fatty acid with the peroxyl radical, which, giving up hydrogen, is converted into a new alkyl radical [4]. Tocopherols on this stage stop POL chain with formation of hydroperoxides of fatty acids; that is why tocopherols are called the chain-terminating antioxidants. Tocopherol molecules, losing hydrogen are converted into the tocopheroxyl radicals (Fig. 2). Tocopheroxyl radicals may be renewed with the help of antioxidant system, which consists of ascorbate and glutathione; renewals with the help of coenzyme $Q$ or covalent interaction with free radicals with further formation of tocopherols, are also possible [16, 17]. Tocopherols are able to neutralize physically or chemically singlet oxygen ${ }^{1} \mathrm{O}_{2}$, which oxidizes membrane lipids, proteins, amino acids, nucleotides, thiols, etc. Physical deactivation of ${ }^{1} \mathrm{O}_{2}$ in chloroplasts is going on by electron transfer from tocopherol to ${ }^{1} \mathrm{O}_{2}$ with creation of ${ }^{3} \mathrm{O}_{2}$. It was showed with using synthetic membranes that one molecule of $\alpha$-tocopherol is able to deactivate up to 120 molecules of ${ }^{1} \mathrm{O}_{2}$ by charge transfer [10]. Tocopherols also may chemi- cally react with ${ }^{1} \mathrm{O}_{2}$. The reaction takes place with formation of intermediate compound - hydroperoxy dienone, which decomposes to form tocopheryl quinone and tocopheryl quinone-2,3-epoxide [18, 19]. The products of tocopherol oxidation in this case are not recycled and are lost [10]. Tocopheryl quinone may be enzymatically converted into $\alpha$-tocopheryl quinol, which is also a potential antioxidant [4]. Tocopheryl quinol in experiments in vitro was more active antioxidant than tocopherol, which can neutralize free radicals and regenerate tocopherol from the tocopheroxyl radicals [20].

\section{Participation of vitamin $\mathrm{E}$ in protecting plants from photoinhibition}

Maintaining a balance between absorbed and utilized light energy is vital for the oxygen photosynthesizing organisms. Changed conditions of environment may cause stresses, which, causing the misbalance, lead to formation of harmful ROS and, as a result, to possible death of the cells. High light intensity can stimulate the formation of ROS. During pho-

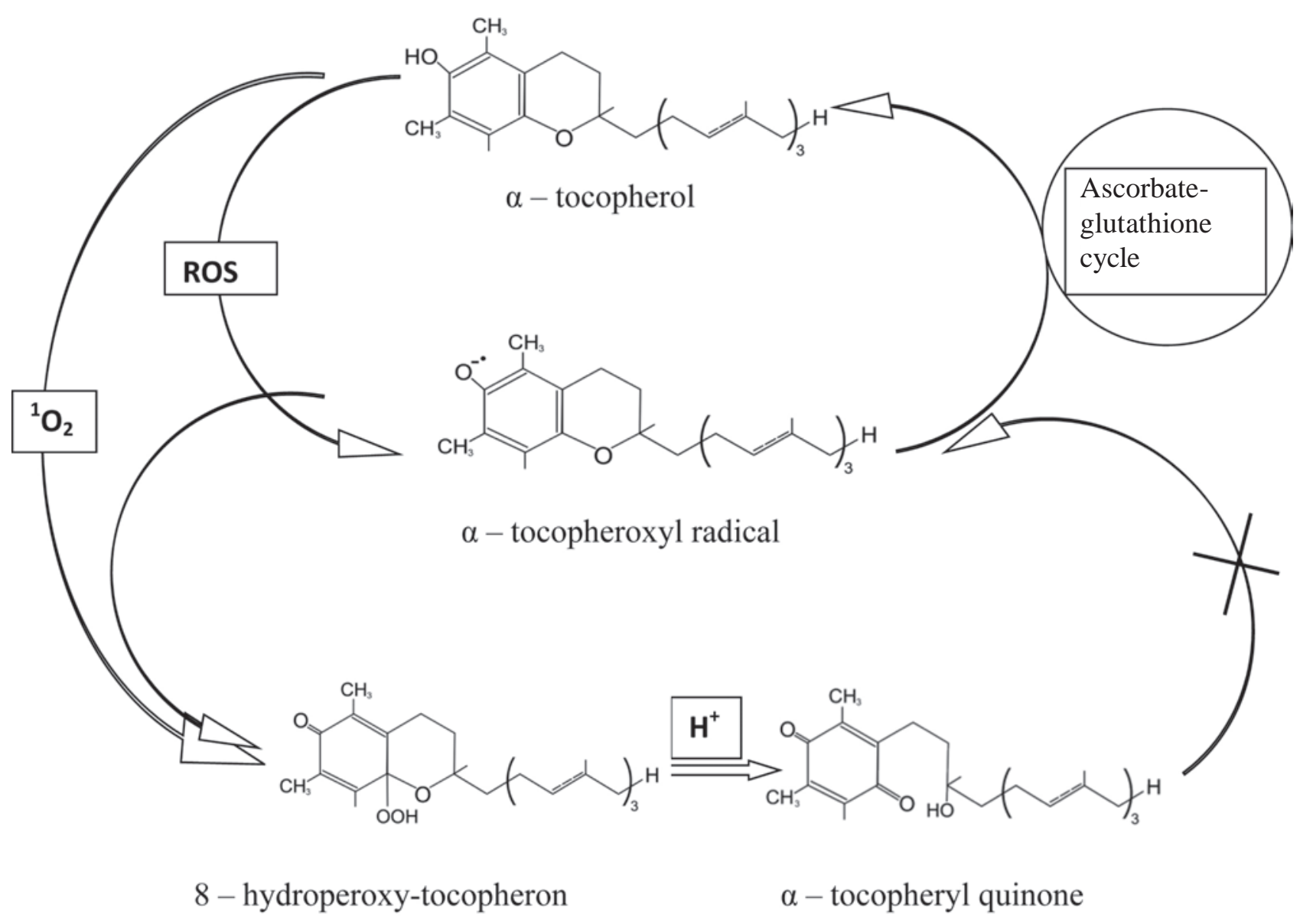

Fig. 2. Oxidative conversion of $\alpha$-tocopherol 
tosynthesis PSII constantly generates singlet oxygen $\left({ }^{1} \mathrm{O}_{2}\right)$, the formation of which is the result of reaction between chlorophyll in the triplet state $\left({ }^{3} \mathrm{P} 680^{*}\right)$ and oxygen in its ground state $\left({ }^{3} \mathrm{O}_{2}\right)$. ROS generated in the chloroplasts of photosynthetic organisms under conditions of high light intensity, causing photoinhibition - light-induced damage of PSII. Together with carotenoids, located within protein-pigment complexes in thylakoid membranes, tocopherol is the predominant fat-soluble antioxidant, localized at the site of light absorption and photosynthetic electron transport. Thus, tocopherols are involved in the protection of pigments and proteins of the photosynthetic apparatus, lipids of the thylakoid membranes from the oxidative damages [21]. Protection of the photosynthetic apparatus from the light-induced oxidative damages is one of the main functions of vitamin E synthesized in plant cells. Several ways of protective action of tocopherols from development of photoinhibition have been investigated.

The reactive center of PSII consists of two homologous polypeptides $\mathrm{D}_{1}$ and $\mathrm{D}_{2}$ with the specific binding sites for important molecular components of the photosynthetic apparatus. It is known that the protein $\mathrm{D}_{1}$ during formation of oxygen is permanently and quickly renewed, especially under the condition of intensive light. The elevated level of singlet oxygen ${ }^{1} \mathrm{O}_{2}$ is the main reason of photoinhibition through the detention of repair PSII, mediated inhibition of protein synthesis at the stage of translation elongation. $\alpha$-Tocopherol, neutralizing ${ }^{1} \mathrm{O}_{2}$, helps restore PSII due to stimulation of the protein synthesis $\mathrm{D}_{1}$ de novo. Owing to their participation in the defense of PSII from ${ }^{1} \mathrm{O}_{2}$, tocopherols are constantly produced and used in plants [22, 23]. The absence of such protection leads to the degradation of protein $\mathrm{D}_{1}$, decay and release of chlorophyll from PSII, resulting in light-induced discoloration of chloroplasts. Secondary ROS, accompanying discoloration of pigments, may also be neutralized by $\alpha$-tocopherols oxidation [3]. It was showed on the example of microalgae Chlamydomonas reinhardtii that under a decrease of $\alpha$-tocopherol level by $80 \%$ under the action of herbicide and light of high intensity $\left(1500 \mu\right.$ mole of photons $\left.\mathrm{m}^{-2} \mathrm{~s}^{-1}\right)$ activity of PS II is fully lost with the simultaneous degradation of protein $\mathrm{D}_{1}$. This proves the antioxidant role of tocopherols in the protection of PSII structural organization under te development of oxidative stress in this alga [18, 23, 24].

Under stress conditions, the cyclic electron transport around PSII is the first step in the protec- tion against photoinhibition. It is assumed that the valence and spin state of heme and non-heme iron are critical in the regulation of linear and cyclic electron flow. The proximity of heme and non-heme iron as binding sites for $\alpha$-tocopherol quinine was found in the native center of PSII. Most likely, the rupture of hydrogen bonds of heme and non-heme iron by prenyl quinones is a mechanism for initiating further electrical and conformational changes of the two iron sites. Moreover, the binding of $\alpha$-tocopheryl quinone with the iron-quinone complex and cytochrome $b_{559}$, significantly modifies the environment of iron atoms, increasing the rigidity of the matrix protein. $\alpha$-Tocopheryl quinone takes influence on the cyclic electron flow and the energy dissipation in PS II. This demonstrates the ability of prenyl quinones to initiate the photoprotective mechanisms in PSII [3]. $\alpha$-Tocopherol inhibits the cyclic transport of electrons around PSII and $\alpha$-tocopheryl quinone activates it. Thus, accumulation of $\alpha$-tocopherols in thylakoids provides protection against the photoinhibition in two ways: deactivation of ${ }^{1} \mathrm{O}_{2}$ and activation of the cyclic transport of electrons around PSII by $\alpha$-tocopheryl quinone [4]. It is assumed that quinone and quinol forms of tocopherol are potential electron-transporting pair in the photosynthetic transport of electrons. The increase of quinone forms of tocopherols is not always associated with changes in the level of tocopherols and may be due to oxidation of its quinol forms [20].

Changes in quantity of vitamin E, which is localized in membranes, can affect the stability and fluidity of membranes. It is proved: there is no mere chance that tocopherols are distributed within the membrane and form complexes with specific membrane components. Vitamin E acts as a stabilizer at the expense of bond formation between the chromanol hydroxyl group of $\alpha$-tocopherol and carboxyl group of phospholipid molecules, increasing the rigidity of membranes [16]. Thus, this provides another way to protect PSII from photoinhibition by reducing the permeability of thylakoid membranes for protons, leading to acidulation of lumen under conditions of high light intensity and activation of violaxanthin de-epoxidase [4].

\section{Studying the functions of tocopherols on the mutant organisms}

All the enzymes which are necessary for synthesis of tocopherols were isolated and characterized in the last decade both in plants (Arabidopsis 
thaliana) and in cyanobacteria (Synechocystis sp. PCC6803). In the process of investigation, the mutants with disrupted specific stages of tocopherol biosynthesis were created, that allowed direct evaluation of tocopherols functions in the photosynthesizing organisms. Mutants of Arabidopsis vitamin e 2 (vte2) and vte1 (and corresponding Synechocystis slr1736 and slr1737) became the main objects of research. Mutants vte2 (slr1736) do not synthesize either tocopherols, or intermediate products of their synthesis, but only redox-active intermediate product of tocopherol synthesis - 2,3-dymethyl-6-phytyl-1,4benzoquinol (DMPBQ) is created in vte1 (slr1737) [25]. The impact of the absence of basic fat-soluble antioxidants on appearing of new phenotypic features was observed in experimental researches. Some of these features were shown both in plant Arabidopsis, and in cyanobacteria Synechocystis sp. PCC6803, that proves conservatism of tocopherol functions.

The presence of tocopherols in seeds during their germination is of vital importance. A higher amount of tocopherols is always accumulated in the plant seeds, than in photosynthetic tissues. Spare lipids of seeds are enriched with polyunsaturated fatty acids, and can be the object of the oxidation by ROS, generated during germination in the processes of $\beta$-oxidation and gluconeogenesis, and seedlings have an additional source of ROS - photosynthesis. Tocopherols as the lipophilic molecules are placed in oil bodies and provide the basic antioxidant protection of seeds and seedlings at the early stages of growth from oxidative stress, thus contributing to their survival [17]. The 5- and 10-fold increase of $\gamma$ and $\delta$ isoforms of tocopherols, respectively, was observed already at the stage of ripening of tomato fruits. Accumulation of $\gamma$-tocopherol - the basic fat-soluble antioxidant of seeds - is connected with regulation of enzymes activity of the tocopherol synthesis [26].

The mutants of Arabidopsis vte1 and vte2, which survived after seed germination, did not show significant phenotypic differences from wildtype plants even under high light intensity that can characterize the degree of tolerance to this type of stress. At the same time, at a lower temperature vte 2 phenotype and, to a lesser extent, vte1, considerably changed: signs of photoinhibition were recorded, the levels of anthocyans increased, growth and seed production was inhibited [12, 25].

Being unique fat-soluble antioxidants, tocopherols prevent oxidation of membrane components in chloroplasts. Total loss of this primary fat-soluble antioxidant was manifested in minimal impact on the sensitivity of Arabidopsis plants to the high levels of light, drought and salinization of soil. Similar results were obtained for the orthologous mutants of Synechocystis. This suggests that tocopherols are not of first importance in plant resistance to stress, and other components of the antioxidant network can compensate for its lack. It was shown that, in contrast to photosynthetic tissues, tocopherols are required to maintain the viability of seeds and limitation of lipid peroxidation during its germination [27]. In their absence a massive lipid oxidation can happen during storage and germination of seeds as a result of the increase in the level of signaling molecules - derived lipids that disorganize antioxidant system in the absence of pathogens.

The absence of tocopherols has impact on the change of hydrocarbon homeostasis of plants by blocking the transport of photoassimilants of the main photosynthetic organs. The same effect was observed in anatomically and physiologically different plants (C3, C4, mono- and dicotyledons). Orthologs of Arabidopsis VTE1 gen - ZmSXD1 and StSXD1 were found in corn (Zea mays), and potato (Solanum tuberosum), respectively. Both mutant organisms zmsxd1 and stsxd1 were different from the wild-type by deponation of callose in plasmodesmata between the cells of sheath and mesophyll in zmsxd1 and in the walls of vessels in stsxd1 [28-30]. The disorder of carbohydrate homeostasis, alteration of the levels of phytohormones and the activation of expression of a number of genes proves the involvement of tocopherols in the signal system of plant cells [28]. The results obtained in the study of mutant organisms Arabidopsis (vte2, vte1) and Synechocystis (slr1736, slr1737), which helped reveal the role of tocopherols in photosynthetic organisms, are low (Table).

\section{Regulatory role of vitamin $\mathrm{E}$ in plant cells}

According to recent data, tocopherols have not only sunscreen and antioxidant function, but are also involved in cell signaling. There is a lack of direct proofs which would explain mechanisms of tocopherols action in regulation of signal transduction and expression of genes. However, the author has proved the involvement of these molecules in the relation with ROS, antioxidants and phytohormones, that have an impact on the transmission of cellular signals in plants [37-39]. Tocopherol, ascorbate and glutathione perform the interdependent control over 
Ta b l e. Studying the functions of tocopherols on the mutant photosynthesizing organisms

\begin{tabular}{|c|c|c|}
\hline $\begin{array}{l}\text { Research object } \\
\text { (acting factor) }\end{array}$ & Phenotypic specificities & Significance of author's results \\
\hline $\begin{array}{l}\text { Plant seedlings } \\
\text { A. thaliana vte } 2 \text { and } \\
\text { vte1 }\end{array}$ & $\begin{array}{l}\text { Seeds of plants vte } 2 \text { have a number of } \\
\text { defects during germination (the in- } \\
\text { crease of cotyledons and the growth of } \\
\text { root were weakened) and significantly } \\
\text { shortened term of life. Seedlings are } \\
\text { not able to the effective lipid metabo- } \\
\text { lism and have significantly increased } \\
\text { the level of major classes of lipid per- } \\
\text { oxidation products. The vte1 mutants } \\
\text { have less differences from wild-type } \\
\text { seedlings }\end{array}$ & $\begin{array}{l}\text { The data demonstrate the important role of } \\
\text { tocopherols in the control of non-enzymatic } \\
\text { lipids peroxidation in seeds during dorman- } \\
\text { cy, germination process and early seedling } \\
\text { development. Intermediate compound of } \\
\text { tocopherol synthesis (DMPBQ) is able to al- } \\
\text { most completely compensate for the absence } \\
\text { of tocopherols (Sattler et al. 2004) [17] }\end{array}$ \\
\hline $\begin{array}{l}\text { A. thaliana vte1 (op- } \\
\text { timal conditions/ } \\
\text { light of high inten- } \\
\text { sity) }\end{array}$ & $\begin{array}{l}\text { In the level of photosynthetic activity, } \\
\text { chlorophyll content and polyunsatu- } \\
\text { rated fatty acids were not significantly } \\
\text { different from wild-type plants, even in } \\
\text { stressful conditions. }\end{array}$ & $\begin{array}{l}\text { Under conditions of moderate oxidative } \\
\text { stress the absence of tocopherols did not } \\
\text { significantly affect the plant due to compen- } \\
\text { satory activation of the other antioxidants. } \\
\text { (Bergmuller et al., 2003) [31] }\end{array}$ \\
\hline $\begin{array}{l}\text { A. thaliana vte } 2 \text { and } \\
\text { vte1 (light of high } \\
\text { intensity + low tem- } \\
\text { perature of growth } \\
\left(2-8^{\circ} \mathrm{C}\right) \text { ) }\end{array}$ & $\begin{array}{l}\text { High level of photoinhibition and POL } \\
\text { in both types of the mutants. General } \\
\text { level of carotenoids is decreased. The } \\
\text { content of zeaxanthin is increased com- } \\
\text { pared with violaxanthin }\end{array}$ & $\begin{array}{l}\text { Tocopherols protect thylakoid membranes } \\
\text { from photooxidative damage. Zeaxanthin as } \\
\text { an antioxidant that works with tocopherol, } \\
\text { partially compensates for the absence of } \\
\text { the latter. DMPBQ cannot protect thylakoid } \\
\text { membranes from the photooxidative dama- } \\
\text { ges. (Havaux et al., 2005) [32] }\end{array}$ \\
\hline $\begin{array}{l}\text { A. thaliana vte2 } \\
\text { and vte1 (light of } \\
\text { high intensity }+ \text { low } \\
\text { growth tempera- } \\
\text { ture) }\end{array}$ & $\begin{array}{l}\text { Export of photoassimilates is inhibited, } \\
\text { the level of soluble sugars and starch } \\
\text { in growing cells is increased through } \\
\text { callose deposition in the walls of the } \\
\text { transport cells of phloem parenchyma. } \\
\text { Photosynthetic transport of electrons is } \\
\text { decreased; plant growth and seed for- } \\
\text { mation are suppressed. The level of an- } \\
\text { thocyans is decreased }\end{array}$ & $\begin{array}{l}\text { Tocopherols are necessary for the forma- } \\
\text { tion and structuring of the walls of transport } \\
\text { cells of phloem parenchyma. Possible way to } \\
\text { influence - the involvement of these mole- } \\
\text { cules in the signal transduction between the } \\
\text { chloroplasts and nucleus, associated with } \\
\text { metabolism of hydrocarbons. (Maeda et al., } \\
\text { 2006) [33] }\end{array}$ \\
\hline A. th & $\begin{array}{l}\text { Increased level of jasmonic acid } 1.6 \text { and } \\
2.4 \text { times on the } 11^{\text {th }} \text { and } 13^{\text {th }} \text { weeks. Ini- } \\
\text { tiation of anthocyans accumulation }\end{array}$ & $\begin{array}{l}\alpha \text {-Tocopherol is involved in signal transduc- } \\
\text { tion thanks to its ability to modulate the } \\
\text { level of phytohormones. (Munne-Bosch et } \\
\text { al., 2007) [34] }\end{array}$ \\
\hline $\begin{array}{l}\text { A. tha } \\
\text { and } v\end{array}$ & $\begin{array}{l}\text { Induction of } 160 \text { genes is observed in } \\
\text { plants vte } 2 \text { which are activated primari- } \\
\text { ly in conditions of biotic and abiotic } \\
\text { stresses. In plants vte } 1 \text { only } 12 \text { genes are } \\
\text { induced, six of which encode cytosolic } \\
\text { heat shock proteins (in mutants of vte } 2 \\
\text { they are also induced) }\end{array}$ & $\begin{array}{l}\text { In the process of seed germination tocophe- } \\
\text { rols have an impact on the expression of a } \\
\text { number of genes. Modulation of non-enzy- } \\
\text { matic peroxidation of lipids with the help of } \\
\text { tocopherols plays an important role in for- } \\
\text { mation of protective reaction of plants. (Sat- } \\
\text { tler et al., 2006) [35] }\end{array}$ \\
\hline
\end{tabular}


Ta ble. (Continuation)

\begin{tabular}{|l|l|l|}
\hline $\begin{array}{l}\text { Synechocystis sp. } \\
\text { PCC 6803 slr0090 } \\
\text { (light of high inten- } \\
\text { sity) }\end{array}$ & $\begin{array}{l}\text { Photoinhibition is developing due to de- } \\
\text { pression of the synthesis of protein } \mathrm{D}_{1} \\
\text { de novo }\end{array}$ & $\begin{array}{l}\text { Tocopherols, neutralizing }{ }^{1} \mathrm{O}_{2} \text {, contribute to } \\
\text { overall protein synthesis. (Inoue et al., 2011) } \\
\text { [22] }\end{array}$ \\
\hline $\begin{array}{l}\text { Synechocys- } \\
\text { tis slr1736 (light of } \\
\text { high intensity ) }\end{array}$ & $\begin{array}{l}\text { The level of carotenoids considerably } \\
\text { decreases }\end{array}$ & $\begin{array}{l}\text { Protection of membrane components from } \\
\text { damage of ROS (Maeda et al., 2005) [36] }\end{array}$ \\
\hline $\begin{array}{l}\text { Synechocystis sp. } \\
\text { PCC 6803 slr1736 } \\
\text { (Autotrophic culti- } \\
\text { vation) }\end{array}$ & $\begin{array}{l}\text { Under the autotrophic condition, photo- } \\
\text { synthesis is activated in cells, the level } \\
\text { of dissolved sugars and glycogen in- } \\
\text { creases. (Under the mixotrophic condi- } \\
\text { tion, photosynthesis is suppressed, the } \\
\text { cells do not assimilate glucose and die) }\end{array}$ & $\begin{array}{l}\text { Optimization of photosynthetic activity and } \\
\text { the support of homeostasis of hydrocarbons, } \\
\text { that may be not connected with antioxidant } \\
\text { features (Sakuragi et al., 2006) [24] }\end{array}$ \\
\hline
\end{tabular}

the level of ROS, which is a critical modulator of gene expression in chloroplasts and nucleus. Data, collected on plant organisms, indicate a direct role of tocopherols in the regulation of redox homeostasis in cells unlike animal organisms in which tocopherols are involved in the regulation of gene expression activity [40]. Tocopherols regulate the degree of oxidative stress, which is associated with tolerance to stress and aging of plants, by neutralizing ROS and preventing the development of POL [37].

The level of tocopherols, as well as that of other antioxidants in plants usually increases in response to a particular stress factor, which stimulates the production of ROS and is mediated by the action of phytohormones (jasmonic acid, abscisic acid). The promotion of POL leads to the formation of jasmonic acid - phytohormone that activates the expression of nuclear genes encoding enzymes of tocopherol synthesis [41, 42]. However, strengthening of photo- and antioxidant protection in the cell may be insufficient for the plant could bear unfavorable conditions and does not stop its ageing. Reducing of tocopherols level through predominance of their degradation over synthesis is of regulatory significance.

For example, tocopherols as intermediates participate in modulation of expression of jasmonatedependent genes, which are usually activated during ageing and damaged by pathogens (Fig. 3) [41]. Thus, if propagation of POL does not stop as a result of antioxidant action of membrane localized tocopherols, jasmonic acid level is increased. Jasmonic acid activates protective mechanisms of cell that include synthesis of anthocyans and other antioxidants. Studies of recent years have shown, that treatment of
Elaeagnus angustifolia callus with jasmonic or salicylic acids stimulate accumulation of $\alpha$-tocopherols in cells [43].

Tocopherol molecules can directly reduce sulfur radicals of membrane proteins, converting them into hydrosulfides or protect indirectly their thiol groups from the oxidation that may be of regulative significance [12].

Tocopheryl quinone (a product of tocopherol oxidation) is also an indicator of oxidative stress, which exceeds in quantity a certain crucial level and becomes a signal for the programmed cell death. Tocopherol quinone is not recycled like tocopheroxyl radical, and a decrease of proportion tocopherol/tocopheryl quinone proves inability of plant organism to withstand the stress conditions. In this case, cell apoptosis protects the plant from lesion propagation [12].

Tocopherols involvement in the provision of plants resistance to stresses is connected not only with their antioxidant features. The data regarding the change of tocopherols quantity in response to the effect of low temperature are ambiguous. As shown on the example of eucalyptus (Eucalyptus gunnii), the transcriptional level of EgSXD1 (ortholog ZmSXD1 of corn) and content of $\alpha$-tocopherol decreases with low temperature stress propagation. Herewith one could observe high level of anthocyans and proline, which was controlled by jasmonic acid. Abscisic acid also did not control the expression of EgSXD1 (ortholog ZmSXD1 of corn) in this condition, in contrast to drought or salt stress conditions [44]. Thus, in this case, the antioxidant role of tocopherols is not involved as the protective mecha- 


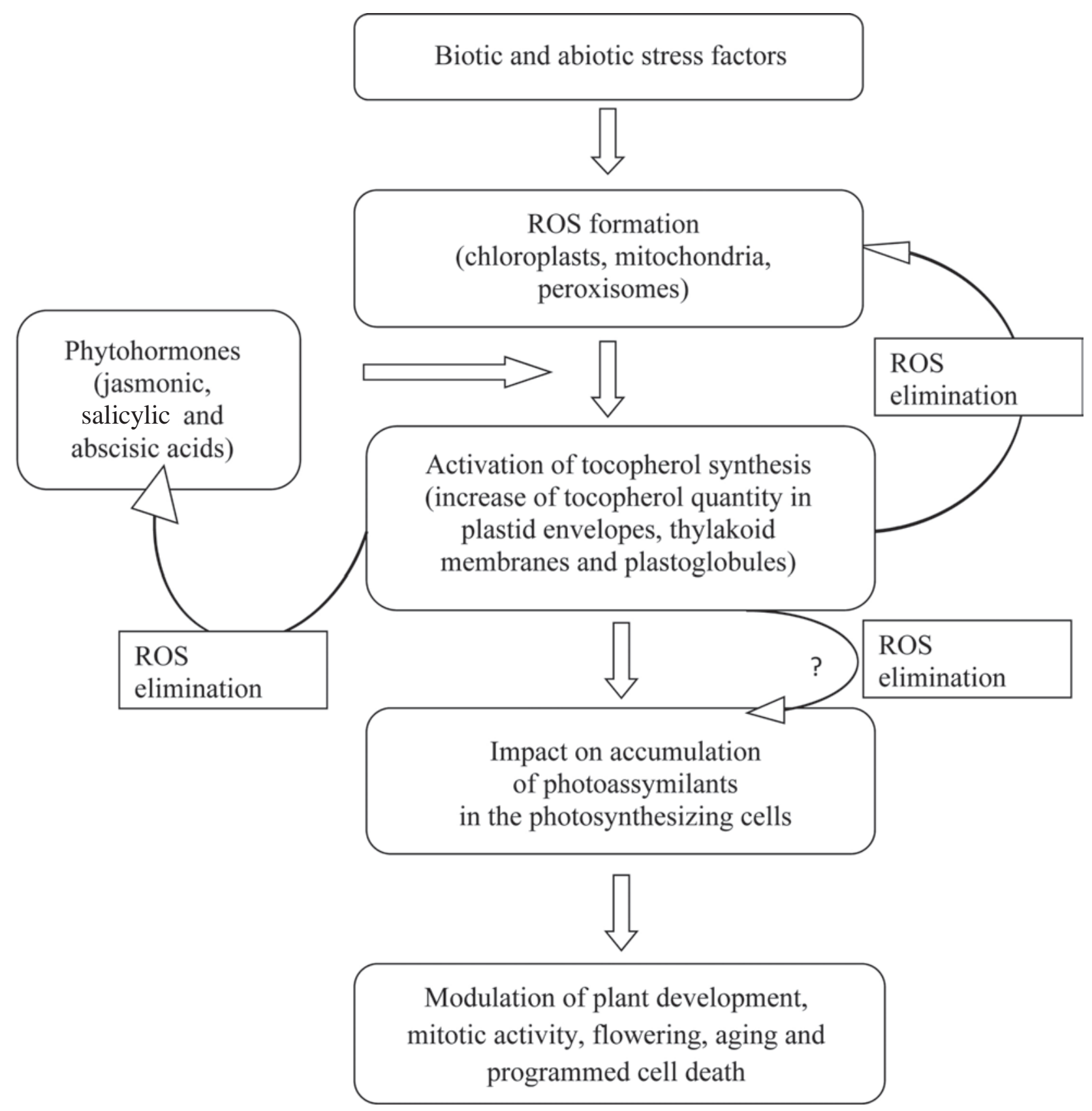

Fig. 3. Scheme of regulative role of tocopherols

nism. Oppression of EgSXD1 expression serves as the mechanism of protection against cold in these plants, the disruption of photoassimilants transport, accumulation of sugars and depression of photosynthesis being its result [44]. The mechanism of tocopherols influence on these processes is not well studied, but it is supposed that it is connected with their participation in cell signal transduction between chloroplasts and nucleus, and bears no relation to the antioxidant function of these molecules. Other authors state, that the deposition of callose may be stimulated by propagation of POL and level of phytohormones. The absence of changes in cell walls of mutant Arabidopsis vte1 under optimal growth conditions, that is the absence of antioxidant stress, proves this presumption [28, 31].

Disruption of fully fledged nutrition of plant through the blocking of photoassimilants in leaves reduces their growth and development. Change of the balanced gradient of sugars between different tissues of a plant is a signal which regulates its development [10]. The wide variety of genes are con- 
trolled by sugars at the transcriptional level, including genes, involved in photosynthesis, nitrogen and carbon metabolism, secondary metabolism and in response to stress in different plants. It means that tocopherols can directly or indirectly influence the sugar level, acting as regulators of cell signals. The same effect was proved in cyanobacteria Synechocystis sp. PCC 6803 slr1736, the cells of which accumulated more sugars and glycogen, than the wild type, that evidences for conservatism of tocopherols property to regulate carbohydrate homeostasis [24].

Thus tocopherols in plant organisms are the main part of antioxidant defense both under optimal conditions and under the effect of stress factors. Plant reaction to stress is dependent on the quantity rate and functioning of these molecules, and varies from abundant ROS deliverance to cells apoptosis. Over the low antioxidant activity of tocopherols one can observe changes in the activity of phytohormone-dependent expression of genes or unbalanced sugar accumulation in plant tissues. The possibility of direct regulation of gene activity of plant cells by vitamin E molecules still remains to be proved and calls for further research.

\section{ФУНКЦЇ̈ ТОКОФЕРОЛІВ У КЛІТИНАХ РОСЛИН ТА ІНШИХ ФОТОСИНТЕЗУЮЧИХ ОРГАНІЗМІВ}

\section{B. М. Мокросноп}

\author{
Інститут ботаніки ім. М. Г. Холодного \\ НАН України, Київ; \\ e-mail: VictoryM6@yandex.ua
}

Синтез токоферолів відбувається тільки в фотосинтезуючих організмах (рослинах, водоростях і більшості ціанобактерій). Токофероли синтезуються в оболонках хлоропластів i розподіляються між мембраною хлоропластів, тилакоїдами і пластоглобулами. Фізіологічне значення токоферолів для людини та тварин добре відомо, однак порівняно мало $є$ даних про їх функціонування в рослинних організмах. Найвивченішою функцією токоферолів є їхня здатність знешкоджувати активні форми кисню і жиророзчинні побічні продукти окислювального стресу. Існують дані про різні механізми участі $\alpha$-токоферолу в захисті фотосистеми II (ФС II) від фотоінгібування як шляхом дезактивації синглетного кисню, що утворюється в ФСІІ, так і зниження протонної проникності тилакоїдних мембран, що веде до закислення люмену за високого освітлення та активації віолоксантин деепоксидази. Продемонстровано додаткову біологічну активність токоферолів, незалежну від їхньої антиоксидантної функції. Основні механізми цих ефектів пов'язані з модуляцією шляхів передачі сигналу за участю токоферолів, а в деяких випадках, активацією транскрипції відповідних генів.

К л ю ч о в і с л о в а: антиоксиданти, пластиди, тилакоїди, хлоропласти, токофероли, токотриеноли, окислювальний стрес, пероксидне окислення ліпідів, фотосинтез, вітамін Е.

\section{ФУНКЦИИ ТОКОФЕРОЛОВ В КЛЕТКАХ РАСТЕНИЙ И ДРУГИХ ФОТОСИНТЕЗИРУЮЩИХ ОРГАНИЗМОВ}

\section{B. М. Мокросноп}

\author{
Институт ботаники им. Н. Г. Холодного \\ НАН Украины, Киев; \\ e-mail: VictoryM6@yandex.ua
}

Синтез токоферолов происходит только в фотосинтезирующих организмах (растениях, водорослях и некоторых цианобактериях). Токоферол синтезируется в оболочках хлоропластов и распределяется между мембраной хлоропластов, тилакоидами и пластоглобулами. Физиологическое значение токоферолов для человека и животных хорошо известно, однако сравнительно мало данных об их функционировании в растительных организмах. Наиболее изученной функцией токоферолов является их способность обезвреживать активные формы кислорода и жирорастворимые побочные продукты окислительного стресса. Имеются данные о различных механизмах участия $\alpha$-токоферола в защите фотосистемы II (ФСІІ) от фотоингибирования как за счет дезактивации синглетного кислорода, образующегося в ФСІІ, так и путем снижения протонной проницаемости тилакоидных мембран, приводящего к закислению люмена при интенсивном освещении и активации виолоксантин деэпоксидазы. Продемонстрирована дополнительная биологическая активность токоферолов, независящая от их антиоксидантной функции. Основные механизмы этих эффектов связаны с модуляцией путей передачи сигнала с участием токоферолов, а в некоторых случаях 
связаны с активацией транскрипции соответствующих генов.

К л ючевы е слов а: антиоксиданты, пластиды, тилакоиды, хлоропласты, токоферолы, токотриенолы, окислительный стресс, пероксидное окисление липидов, фотосинтез, витамин Е.

\section{References}

1. Hussain N., Irshad F., Jabeen Z., Shamsi I., Jiang L. Correlations between tocopherol and fatty acid components in germplasm collections of Brassica oilseeds. J. Agric. Food Chem. 2013;61:6137-6149.

2. Bellock O. New topics in vitamin E research. New York: Nova science publishers, 2007. 167 p.

3. Preedy V., Watson R. The encyclopedia of vitamin E. London: CABI Publishing, 2007. 945 p.

4. Munne-Bosch S. $\alpha$-Tocopherol: a multifaceted molecule in plants. Vitam. Horm. 2007;76:375-392.

5. Lichtenthaler H. Biosynthesis, accumulation and emission of carotenoids, alpha-tocopherol, plastoquinone, and isoprene in leaves under high photosynthetic irradiance. Photosynth. Res. 2007;92:163-179.

6. Szymańska R., Kruk J. Plastoquinol is the main prenyllipid synthesized during acclimation to high light conditions in Arabidopsis and is converted to plastochromanol by tocopherol cyclase. Plant Cell Physiol. 2010;51(4):537-545.

7. Havaux M., Eymery F., Porfirova S., Rey P., Dormann P. Vitamin E protects against photoinhibition and photooxidative stress in Arabidopsis thaliana. Plant Cell. 2005;17:34513469.

8. Munne-Bosch S., Alegre L. The function of tocopherols and tocotrienols in plants. Crit. Rev. Plant Sci. 2002;21(1):31-57.

9. Lichtenthaler H. K., Prenzel U., Douce R., Joyard J. Localization of prenylquinones in the envelope of spinach chloroplasts. Biochim. Biophys. Acta. 1981;641:99-105.

10. Szarka A., Tomasskovics B., Banhegyi G. The ascorbate-glutathione- $\alpha$-tocopherol triad in abiotic stress response. Int. J. Mol. Sci. 2012;13:4458-4483.

11. Collin V. C., Eymery F., Genty B., Rey P., Havaux M. Vitamin $\mathrm{E}$ is essential for the tolerance of Arabidopsis thaliana to metalinduced oxidative stress. Plant Cell Environ. 2008;31:244-257.
12. Li Y., Wang Z., Sun X., Tang K. The current opinions on the functions of tocopherol based on the genetic manipulation of tocopherol biosynthesis in plants. J. Integr. Plant Biol. 2008;50(9):1057-1069.

13. Niki E., Noguch N. Dynamics of antioxidant action of vitamin E. Acc. Chem. Rec. 2004;37:45-51.

14. Mène-Saffrané L., Jones A. D., DellaPenna D. Plastochromanol-8 and tocopherols are essential lipid-soluble antioxidants during seed desiccation and quiescence in Arabidopsis. Proc. Natl. Acad. Sci. USA. 2010;107:17815-17820.

15. Gill S., Tuteja N. Reactive oxygen species and antioxidant machinery in abiotic stress tolerance in crop plants. Plant Physiol. Biochem. 2010;48:909-930.

16. Abbasi A. Functional analysis of tocopherol biosynthesis in plants. Aus Tehran: IRI, 2007. $171 \mathrm{p}$.

17. Sattler S., Gilliland S., Magallanes-Lundback M., Pollard M., DellaPenna D. Vitamin E is essential for seed longevity and for preventing lipid peroxidation during germination. Plant Cell. 2004;16(8):419-1432.

18. Kruk J., Hollander-Czytko H., Oettmeier W., Trebst A. Tocopherol as singlet oxygen scavenger in photosystem II. J. Plant Physiology. 2005;162:749-757.

19. Krieger-Liszkay A., Trebst A. Tocopherol is the scavenger of singlet oxygen produced by the triplet states of chlorophyll in the PSII reaction centre. J. Exp. Bot. 2006;57(8):677-1684.

20. Kruk J., Strzalka K. Occurrence and function of $\alpha$-tocopherol quinine in plants. J. Plant Physiol. 1995;145:405-409.

21. Zhirong L., Keasling J., Niyogi K. Overlapping photoprotective of vitamin $\mathrm{E}$ and carotenoids in Chlamydomonas. Plant Physiology. 2012;158(1):313-323.

22. Inoue S., Ejima K., Iwai E, Hayashi H., Appel J., Tyystjarvi E., Murata N., Nishiyama Y. Protection by $\alpha$-tocopherol of the repair of photosystem II during photoinhibition in Synechocystis sp. PCC 680. Biochim. Biophys. Acta. 2011;1807(2):236-241.

23. Trebst A., Depka B., Hollander-Czytko H. A specific role for tocopherol and of chemical singlet oxygen quenchers in the maintenance of photosystem II structure and function in Chlamydomonas reinhardtii. FEBS Lett. 2002;516(1-3):156-160. 
24. Sakuragi Y., Maeda H., DellaPenna D., Bryant D. $\alpha$-Tocopherol plays a role in photosynthesis and macronutrient homeostasis of the cyanobacterium Synechocystis sp. PCC 6803 that is independent of its antioxidant function. Plant Physiol. 2006;141:508-521.

25. Maeda H., DellaPenna D. Tocopherol functions in photosynthetic organisms. Curr. Opin. Plant Biol. 2007;10(2):260-265.

26. Quadrana L., Almeida J., Otaiza S., Duffy T., Correa da Silva J., de Godoy F., Asis R., Bermudez L., Fernie A., Carrari F., Rossi M. Transcriptional regulation of tocopherol biosynthesis in tomato. Plant. Mol. Biol. 2013;81:309-325.

27. Mène-Saffrané L., DellaPenna D. Biosynthesis, regulation and functions of tocochromanols in plants. Plant Physiol. Biochem. 2010;8:301-309.

28. Hofius D., Hajirezaei M.-R., Geiger M., Tschiesch H., Melzer M., Sonnewald U. RNAi-mediated tocopherol deficiency impairs photoassimilate export in transgenic potato plants. Plant Physiology. 2004;135(3):1256-1268.

29. Botha C.E.J., Cross R.H.M., van Bel A.J.E., Peter C.I. Phloem loading in the sucrose-exportdefective (SXD-1) mutant maize is limited by callose deposition at plasmodesmata in bundle sheath-vascular parenchyma interface. Protoplasma. 2000;214:65-72.

30. Sattler S., Cahoon E., Coughlan S., DellaPenna D. Characterization of tocopherol cyclases from higher plants and cyanobacteria. Evolutionary implications for tocopherol synthesis and function. Plant Physiol. 2003;132(4):2184-2195.

31. Bergmuller E., Porfirova S., Dormann P. Characterization of an Arabidopsis mutant deficient in $\gamma$-tocopherol methyltransferase. Plant Mol. Biol. 2003;52(6):1181-1190.

32. Havaux M., Eymery F., Porfirova S., Rey P., Dormann P. Vitamin E protects against photoinhibition and photooxidative stress in Arabidopsis thaliana. Plant Cell. 2005;17(12):3451-3469.

33. Maeda H., Song W., Sage T., DellaPenna D. Tocopherols play a crucial role in lowtemperature adaptation and phloem loading in Arabidopsis. Plant Cell. 2006;18(10):2710-2732.
34. Munne-Bosch S. $\alpha$-Tocopherol: a multifaceted molecule in plants. Vitam. Horm. 2007;76:375-392.

35. Sattler S., Mène-Saffrané L., Farmerb E., Krischke M., Mueller M., DellaPenna D. Nonenzymatic lipid peroxidation reprograms gene expression and activates defense markers in Arabidopsis tocopherol-deficient mutants. Plant Cell. 2006;18(12):3706-3720.

36. Maeda H., Sakuragi Y., Bryant D., DellaPenna D. Tocopherols protect Scynechocystis sp. Strain PC 6803 from lipid peroxidation. Plant Physiol. 2005;138(3):1422-1435.

37. Munne-Bosch S. Linking tocopherols with cellular signaling in plants. New Phytologist. 2005;166(2):363-366.

38. Munne-Bosch S., Falk J. New insights into the function of tocopherols in plants. Planta. 2004;218(3):323-326.

39. Lushchak V., Semchuk N. Tocopherol biosynthesis: chemistry, regulation and effects of environmental factors. Acta Physiol. Plant. 2012;34(2): DOI 10.1007/s11738-012-0988-9.

40. Azzi A., Stocker A. Vitamin E: non-antioxidant roles. Prog. Lipid Res. 2000;39:231-255.

41. Sandorf I., Hollander-Czytko H. Jasmonate is involved in the induction of tyrosine aminotransferase and tocopherol biosynthesis in Arabidopsis thaliana. Planta. 2002;216:173-179.

42. Schaller F. Enzymes of the biosynthesis of octadecanoid-derived signaling molecules. J. Exp. Bot. 2001;52:11-23.

43. Badrhadad A., Piri K., Ghiasvand T. Increasing of alpha-tocopherol in cell suspension cultures Elaeagnus angustifolia L. Intl. J. Agri. Crop. Sci. 2013;5(12):1328-1331.

44. Kayal W., Keller G., Debayles C., Kumar R., Weier D., Teulieres C., Marque C. Regulation of tocopherol biosynthesis through transcriptional control of tocopherol cyclase during cold hardening in Eucalyptus gunnii. Physiol. Plantarum. 2006;126:212-223.

Received 29.10.2013 